\title{
Mannose-sensitive Haemagglutinins in Adherence of Vibrio cholerae eltor to Intestine
}

\author{
By J. W. BHATTACHARJEE AND BRAHM S. SRIVASTAVA \\ Cholera Immunology, Microbiology Division, Central Drug Research Institute, \\ Lucknow 226001, India
}

(Received 18 January 1978; revised 7 May 1978)

\section{INTRODUCTION}

Vibrio cholerae agglutinates red blood cells from chicken, sheep, rabbit and humans (for review of early work, see Lankford \& Legsomburana, 1965) and this characteristic of vibrios was exploited to differentiate the classical and eltor biotypes (Barua \& Mukherjee, 1963, 1965; Finkelstein \& Mukerjee, 1963). Attempts to associate haemagglutination with fimbriae on the surface of $V$. cholerde have not been conclusive (Barua \& Chatterjee, 1964; Tweedy et al., 1968).

Attachment of bacteria to mucosal cells is probably an essential step in colonization. The mechanisms of haemagglutination and adherence of vibrios to brush border membrane of rabbit intestine may be similar (Jones et al., 1976). A few reports with other pathogenic bacteria suggest a correlation between haemagglutination and adherence to mucosal cells, and surface antigens facilitating colonization of intestine have been identified (Stirm et al., 1967; Jones \& Rutter, 1972, 1974; Burrows et al., 1976; Koransky et al., 1975; Buchanan \& Pearce, 1976). Mannose or mannosides inhibit binding of Escherichia coli to erythrocytes and to intestinal epithelial cells (Duguid \& Gillies, 1957; Jones \& Rutter, 1974; Ofek et al., $1977)$ and the adherence of $V$. cholerae to brush border membranes via L-fucose receptors has been reported (Jones \& Freter, 1976). The apparent correlation between haemagglutination and adhesion suggested the possibility that carbohydrate receptors might be involved in vibrio adhesion. We have found that mannose-sensitive haemagglutinins play a role in the adherence of vibrios to intestine and that mucosal cells bear mannose receptors.

\section{METHODS}

Organisms. Vibrio cholerae strain $\mathrm{KB} 207$ was selected as wild-type eltor Ogawa and is highly pathogenic in experimental models of cholera. Following $N$-methyl- $N^{\prime}$-nitro- $N$-nitrosoguanidine treatment (Adelberg et al., 1965) of strain $\mathrm{KB} 207$, several non-motile and a motile but poorly adhering strain (designated as CD11) were isolated by Ranjana Srivastava in this laboratory (Table 1).

Growth condition and media. Bacteria were grown overnight at $37^{\circ} \mathrm{C}$ on nutrient agar slants [Difco nutrient broth solidified with $1 \%(w / v)$ Oxoid agar]. Growth was harvested in phosphate buffered saline (PBS; Cruickshank, 1966). The 3 or $18 \mathrm{~h}$ broth cultures were obtained by diluting organisms from slant cultures into fresh nutrient broth and shaking gently at $37^{\circ} \mathrm{C}$. Viable counts were made on nutrient agar.

Haemagglutination $(H A)$. Human red blood cells (r.b.c.), group B, were collected, washed three times in PBS and resuspended to $1 \%(\mathrm{v} / \mathrm{v})$. Serial dilutions of bacteria in PBS were made in microtitre plates (Cooke Engineering Co., Alexandria, Virginia, U.S.A.) using $0.05 \mathrm{ml}$ microdiluters. An equal volume of r.b.c. was added, mixed and the plates were then incubated at $22^{\circ} \mathrm{C}$ for $1 \mathrm{~h}$. The highest dilution giving $\mathrm{HA}$ was recorded. The effect of $\mathrm{D}$-mannose $(\mathrm{BDH})$ on HA was examined by including D-mannose $\left(100 \mu \mathrm{g} \mathrm{ml}^{-1}\right) \mathrm{in}^{-}$ the PBS.

Adherence. Vibrios diluted in $5 \mathrm{ml}$ PBS to $10^{7}$ cells $\mathrm{ml}^{-1}$ were exposed to freshly isolated rabbit intestine discs $(10 \mathrm{~mm}$ diam.) for $30 \mathrm{~min}$. The discs were washed twice with PBS $(20 \mathrm{ml})$ to remove non-adhering vibrios, homogenized and the viable count of the bacteria adhering to discs was made. To examine the effect 
Table 1. Strains of $V$. cholerae eltor and their characteristics

\begin{tabular}{|c|c|c|c|c|c|c|}
\hline \multirow[b]{2}{*}{ Strain } & \multirow[b]{2}{*}{ Culture } & \multicolumn{2}{|c|}{ HA titre (reciprocal) } & \multicolumn{2}{|c|}{ Adherence index* } & \multirow[b]{2}{*}{ Motility } \\
\hline & & $\begin{array}{l}\text { Without } \\
\text { mannose }\end{array}$ & $\begin{array}{c}\text { With } \\
\text { D-mannose } \\
\left(100 \mu \mathrm{g} \mathrm{ml}^{-1}\right)\end{array}$ & $\begin{array}{l}\text { Without } \\
\text { mannose }\end{array}$ & $\begin{array}{c}\text { With } \\
\text { D-mannose } \\
\left(1 \mathrm{mg} \mathrm{ml}^{-1}\right)\end{array}$ & \\
\hline КВ207 & Agar & 64 & 4 & $6 \cdot 3$ & $1 \cdot 2$ & Motile \\
\hline CD11 & $\begin{array}{l}\text { Broth } \\
\text { Agar } \\
\text { Broth }\end{array}$ & $\begin{array}{l}64 \\
64 \\
64\end{array}$ & $\begin{array}{l}64 \\
64 \\
64\end{array}$ & $\begin{array}{l}0.35 \\
0.06 \\
0.1\end{array}$ & $\begin{array}{l}0.47 \\
\text { ND } \\
\text { ND }\end{array}$ & $\begin{array}{l}\text { Motile } \\
\text { Motile } \\
\text { Motile }\end{array}$ \\
\hline $\mathrm{CD} 12$ & $\begin{array}{l}\text { Agar } \\
\text { Broth }\end{array}$ & $\begin{array}{l}32 \\
64\end{array}$ & $\begin{array}{l}32 \\
64\end{array}$ & $\begin{array}{l}0.02 \\
\text { ND }\end{array}$ & $\begin{array}{l}\text { ND } \\
\text { ND }\end{array}$ & $\begin{array}{l}\text { Non-motile } \\
\text { Non-motile }\end{array}$ \\
\hline
\end{tabular}

ND, Not done.

* Adherence index is the number of vibrios adhering expressed as a percentage of the number of vibrios to which the slice of intact intestinal mucosa was exposed. Indices given are the average from three to five experiments.

of D-mannose on adherence, $10^{9}$ vibrios were exposed to D-mannose $\left(1 \mathrm{mg} \mathrm{ml}^{-1}\right)$ for $15 \mathrm{~min}$. The bacteria were then diluted 100-fold in PBS and exposed to intestine discs as described above.

Motility. Bacterial motility was observed microscopically and quantified using $10 \mu \mathrm{l}$ micropipettes (Kimble disposable; Illinois, U.S.A.) according to Adler $(1969,1973)$. The non-motile mutants were characterized as being aflagellate by electron microscopy.

\section{RESULTS}

The broth culture of $\mathrm{KB} 207$ was less adhesive than the agar culture although haemagglutinins were present in both (Table 1). Haemagglutinins from agar cultures were mannosesensitive (m.s.) and a 16-fold drop in HA titre was observed, whereas broth cultures, either shaken or unshaken for 3 or $18 \mathrm{~h}$, consistently gave mannose-resistant (m.r.) haemagglutination. D-Mannose also inhibited the adherence of agar cultures and pre-incubation of agar cultures with the sugar led to a significant fall in the adherence index. In contrast, the adherence of broth cultures, which had m.r. haemagglutinins and were less adhesive than agar cultures, was not affected by D-mannose. Incubation of the intestinal discs, instead of vibrios, with D-mannose for $15 \mathrm{~min}$ did not inhibit adherence.

Several non-motile strains were isolated and all produced haemagglutinins. The HA titres obtained with agar cultures of one such strain (CD12) were lower than those obtained for KB207 and a prozone was usually observed, although $3 \mathrm{~h}$ shake broth cultures consistently gave high HA titres like KB207 (Table 1). Strain CD12 exhibited m.r. haemagglutination in both broth and agar cultures, and the adherence indices were very low for all the non-motile strains.

Strain CD11 was as motile as the parent strain KB207 and was the least adhesive among the motile strains examined. There was no difference in the adherence of agar or broth cultures. Like CD12, this strain exhibited only m.r. haemagglutination and $3 \mathrm{~h}$ broth cultures gave optimal HA titres (Table 1).

Several other wild-type classical strains of $V$. cholerae were studied. Although all showed good adhesion, some were HA positive and others negative. The HA negative strains were grown under several different conditions (for example, in tryptone and peptone water, on agar, in broth for 3,18 and $72 \mathrm{~h}$ with three subcultures in fresh broth) but were always HA negative.

\section{DISCUSSION}

From our studies, no direct relationship was found between HA and adherence of $V$. cholerae to intestine. Non-adhesive strains derived from $\mathrm{Kв} 207$, both motile and nonmotile, possessed HA activity. Of the several adhesive strains examined, some were HA 
positive and others negative. The HA activity of non-motile aflagellate mutants of classical and eltor $V$. cholerae has been reported previously (Sweet, C. E., 1963; cited in Lankford \& Legsomburana, 1965). However, in more recent work, Jones \& Freter (1976) found that non-motile mutants of classical vibrios were HA negative and non-adhesive.

The agar cultures were more adhesive than the broth cultures, a finding that is contrary to those of Jones et al. (1976). There is no obvious explanation for this difference except that we used eltor vibrios whereas Jones et al. (1976) used classical vibrios.

The adherence and HA activity of broth and agar cultures of KB207 and their differential sensitivity to D-mannose suggested that with this strain the m.s. haemagglutinins synthesized in agar cultures play a role in adhesion of vibrios to intestinal mucosa. The non-adhesive strains, CD11 and CD12, exhibited only m.r. haemagglutination, which thus supports this conclusion. In KB207, D-mannose caused inhibition of both HA and the adherence of agar cultures. It appears, therefore, that some other haemagglutinins present in broth culture might be responsible for the residual adherence of vibrios to intestinal mucosa. D-Mannose sensitivity of HA by eltor vibrios has been reported previously (Barua \& Chatterjee, 1964; Barua \& Mukherjee, 1965).

Pretreatment with D-mannose of agar cultures producing m.s. haemagglutinins greatly impaired their adhesiveness. Thus it seems that mannose-containing receptors are located on the intestinal mucosal surfaces to which vibrios adhered. The observations that strains CD1 1 and CD12 adhered poorly and exhibited only m.r. haemagglutinins and that D-mannose had no effect on the adhesiveness of кв207 producing m.r. haemagglutinins support this conclusion. Mannose-resistant adhesion of broth cultures suggested that vibrios also adhered to mucosal surfaces via receptors other than mannose-containing receptors.

Jones \& Freter (1976) have described inhibition of adherence of vibrios to isolated brush border membranes by L-fucose and, to a lesser extent, by D-mannose (since there was no additive effect, it is likely that $\mathrm{D}$-mannose forms part of the L-fucose receptor). Yet, using slices of intact intestinal mucosa, similar to those used by us, neither L-fucose nor D-mannose inhibited adhesion of vibrios (Freter \& Jones, 1976).

We are grateful to Dr Nitya Nand, Director of the Institute, for facilities and interest, to Ranjana Srivastava for the gift of mutants before publication, to the Indian Council of Medical Research for financial assistance to J.W.B., to Mr A. K. Sarkar for technical assistance and to Drs A. C. Shipstone and V. K. Bajpai for electron microscopy of nonmotile mutants. This is communication no. 2392 of this Institute.

\section{REFERENCES}

Adelberg, E. A., Mandel, M. \& Chen, G. C. C. (1965). Optimal conditions for mutagenesis by $N$-methyl- $N^{\prime}$-nitro- $N$-nitrosoguanidine in Escherichia coli $\mathrm{K} 12$. Biochemical and Biophysical Research Communications 18, 788-792.

AdLER, J. (1969). Chemoreceptors in bacteria. Science 166, 1588-1597.

AdLer, J. (1973). A method for measuring chemotaxis and use of the method to determine optimal conditions for chemotaxis by Escherichia coli. Journal of General Microbiology 74, 77-91.

Barua, D. \& Chatterjee, S. N. (1964). Electron microscopy of $\mathrm{El}$ Tor vibrios. Indian Journal of Medical Research 52, 828-829.

Barua, D. \& Mukherjee, A. C. (1963). Direct haemagglutination for differentiating El Tor vibrios from Vibrio cholerae. Bulletin of the Calcutta School of Tropical Medicine 11, 85-86.
Barua, D. \& Mukherjee, A. C. (1965). Haemagglutinating activity of El Tor vibrios and its nature. Indian Journal of Medical Research 53, 399-404.

Buchanan, T. M. \& Pearce, W. A. (1976). Pili as mediators of attachment of gonococci to human erythrocytes. Infection and Immunity 13, 14831489.

Burrows, M. R., Sellwood, R. \& Gibbons, R. A. (1976). Haemagglutinating and adhesive properties associated with the K99 antigen of bovine strains of Escherichia coli. Journal of General Microbiology 96, 269-275.

Cruickshank, R. (1966). Medical Microbiology. Edinburgh and London: Livingstone.

Duguid, J. P. \& Gillies, R. R. (1957). Fimbriae and adhesive properties in dysentery bacilli. Journal of Pathology and Bacteriology 74, 397-411. 
Finkelstein, R. A. \& MukerJeE, S. (1963). Haemagglutination. A rapid method for differentiating Vibrio cholerae from El Tor vibrios. Proceedings of the Society for Experimental Biology and Medicine 112, 355-359.

FreTER, R. \& Jones, G. W. (1976). Adhesive properties of Vibrio cholerae: nature of the interaction with intact mucosal surfaces. Infection and Immunity 14, 246-256.

JONES, G. W. \& Freter, R. (1976). Adhesive properties of Vibrio cholerae: nature of the interaction with isolated rabbit brush border membranes and human erythrocytes. Infection and Immunity 14, 240-245.

JoNes, G. W. \& RutTer, J. M. (1972). Role of the K88 antigen in the pathogenesis of neonatal diarrhoea caused by Escherichia coli in piglets. Infection and Immunity 6, 918-927.

Jones, G. W. \& RutTer, J. M. (1974). The association of $\mathrm{K} 88$ antigen with haemagglutinating activity in porcine strains of Escherichia coli. Journal of General Microbiology 84, 135-144.

Jones, G. W., Abrams, G. D. \& Freter, R. (1976). Adhesive properties of Vibrio cholerae: adhesion to isolated rabbit brush border membranes and haemagglutinating activity. Infection and Immunity 14, 232-239.

Koransky, J. R., Scales, R. W. \& Kraus, S. J. (1975). Bacterial haemagglutination by Neisseria gonorrhoea. Infection and Immunity 12, 495-498.

LANKFord, C. E. \& Legsomburana, U. (1965). Virulence factors of choleragenic vibrios. In Proceedings of the Cholera Research Symposium, 1965, Honolulu, Hawaii, pp. 109-120. Washington: U.S. Government Printing Office.

Ofek, I., Mirelman, D. \& Sharon, N. (1977). Adherence of Escherichia coli to human mucosal cells mediated by mannose rereptors. Nature, London 265, 623-625.

Stirm, A., Ørskov, F., Ørskov, I. \& MANSA, B. (1967). Episome carried surface antigen K88 of Escherichia coli. III. Morphology. Journal of Bacteriology 93, 740-745.

Tweedy, J. M., Park, R. W. A. \& Hodikiss, W. (1968). Evidence for presence of fimbriae (pili) on vibrio species. Journal of General Microbiology 51, 235-244. 